\title{
Ductus Arteriosus
}

National Cancer Institute

\section{Source}

National Cancer Institute. Ductus Arteriosus. NCI Thesaurus. Code C52854.

An embryonic blood vessel that allows blood to bypass the lungs by connecting the pulmonary artery and the proximal descending aorta. It the vast majority of neonates it atrophies at birth, becoming the ligamentum arteriosum. 